\title{
Postinfarction dissecting intramyocardial haematoma in a patient treated with immunosuppressant
}

\author{
Koji Sakata, Toshihiro Tsuruda, Takuroh Imamura, Kazuo Kitamura \\ Department of Internal Medicine, Circulatory and Body Fluid Regulation, University of Miyazaki, Miyazaki, Japan
}

Correspondence to Dr Koji Sakata, koudieee@gmail.com

\section{DESCRIPTION}

A 58-year-old Japanese man who had been taking immunosuppressant tacrolimus ( $2 \mathrm{mg} /$ day) for rheumatoid arthritis over 3 years was admitted with deterioration of exertion. He had complained of chest discomfort a month earlier. ECG exhibited a OS pattern and ST elevation in the anterior precordial leads. Transthoracic echocardiogram revealed an impaired left ventricle (LV) function with akinesis of the anteroseptal wall. A low echoic cavity was observed at the apex of LV (figure 1A, video 1), and colour Doppler imaging demonstrated the turbulent pulsatile flow in the cavity (figure $1 \mathrm{~B}$, video 2 ). Moreover, three-dimensional (3D) echocardiogram showed dynamic movement of the dissecting myocardium in the LV chamber (figure 1C, video 3).

Coronary angiography performed on the admission day confirmed total occlusion of the left anterior descending artery. This was identified as a dissecting intramyocardial haematoma (DIH) due to acute myocardial infarction (AMI). Because the patient rejected surgical treatment, we decided to observe him conservatively. We prescribed an ACE inhibitor (enalapril $2.5 \mathrm{mg} /$ day) and $\beta$-blocker (carvedilol $5 \mathrm{mg} /$ day). Anticoagulation therapy would also progress dissection, ${ }^{1}$ and we did not use antiplatelet or anticoagulation agents for this patient. The neo-cavity was progressively clotting (6 days, figure 2A; 12 days, figure $2 \mathrm{~B}$ ), thrombosed ( 6 months, figure $2 \mathrm{C}$ ) and regressed 14 months later (figure 2D).

$\mathrm{DIH}$ is a rare form of cardiac rupture that can occur as a complication following AMI. The impaired remodelling in a subacute phase is suggested to be the pathogenesis of DIH. We discuss that tacrolimus might contribute to a delay in a healing process, promoting intramyocardial haemorrhage, as the compound is reported to attenuate the accumulation of mononuclear cells, preventing scar formation. ${ }^{2}$ Contrast echocardiography, Doppler colour
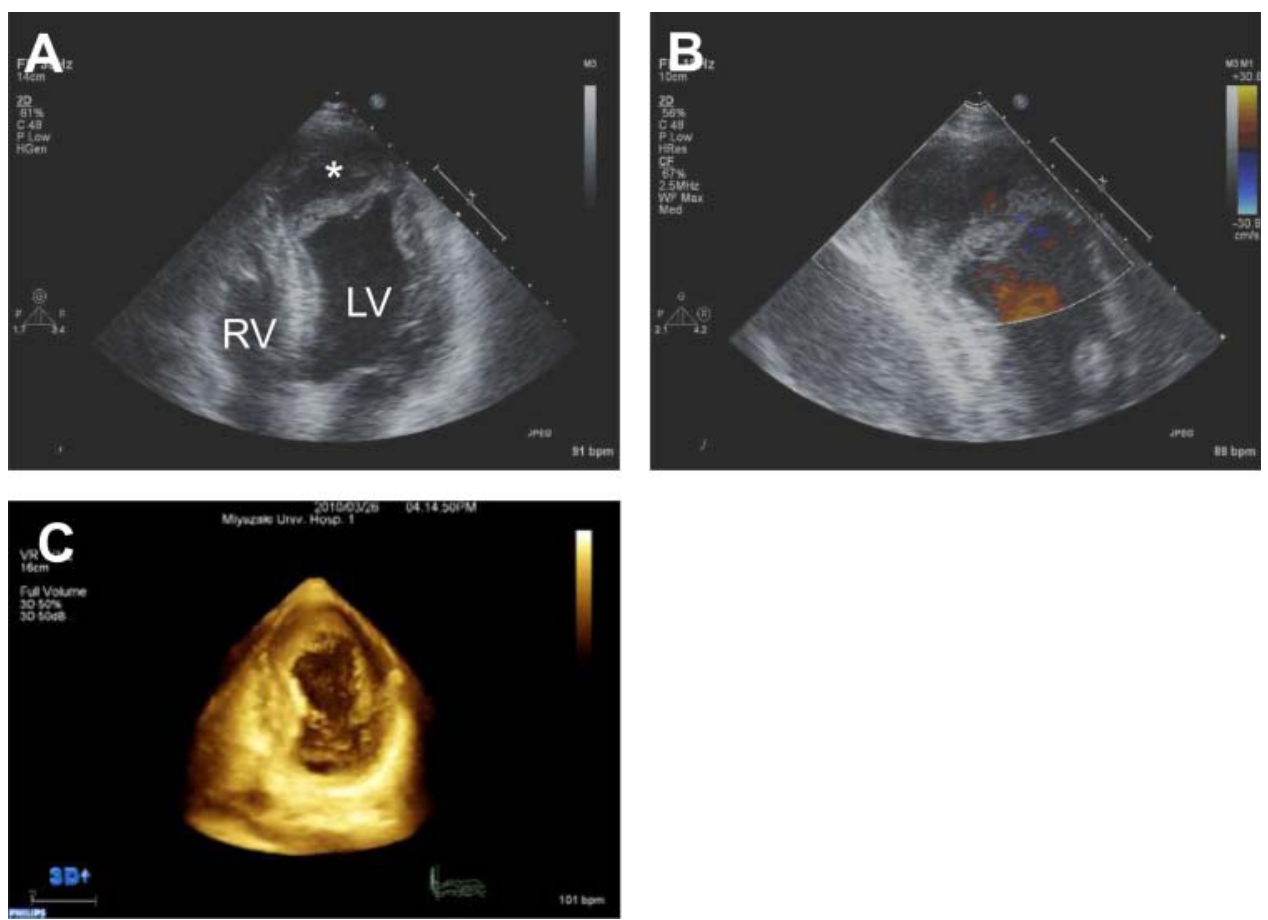

Figure 1 Transthoracic four-chamber imaging (A), Doppler colour flow imaging (B) and three-dimensional echocardiogram (C) on the admission day. Asterisk indicates the neo-cavity of dissecting intramyocardial haematoma. LV, left ventricle; RV, right ventricle. 


\section{BMJ Case Reports}
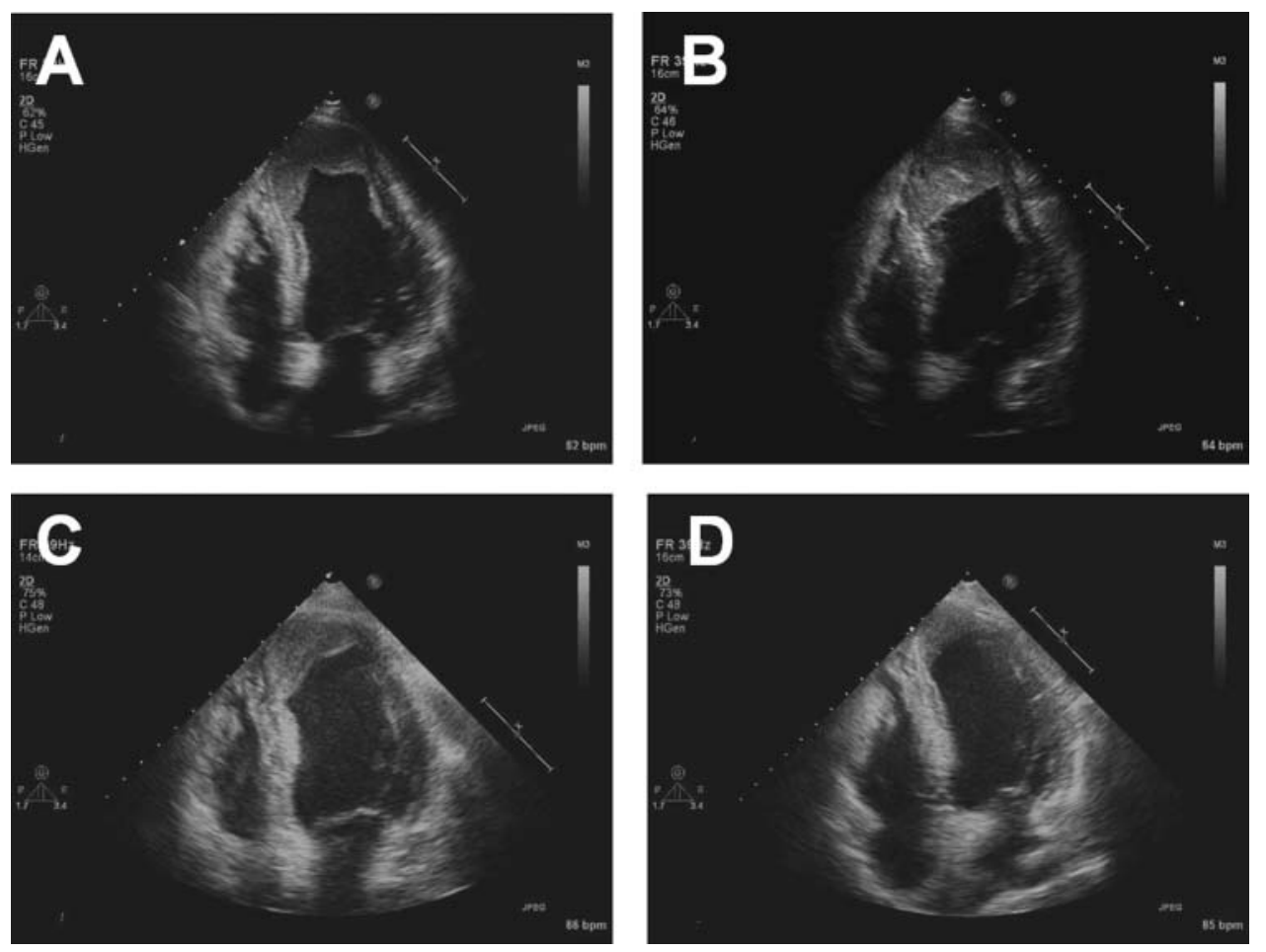

Figure 2 Spontaneous regression of dissecting intramyocardial haematoma at 6 days (A), 12 days (B), 6 months (C) and 14 months (D) after admission.

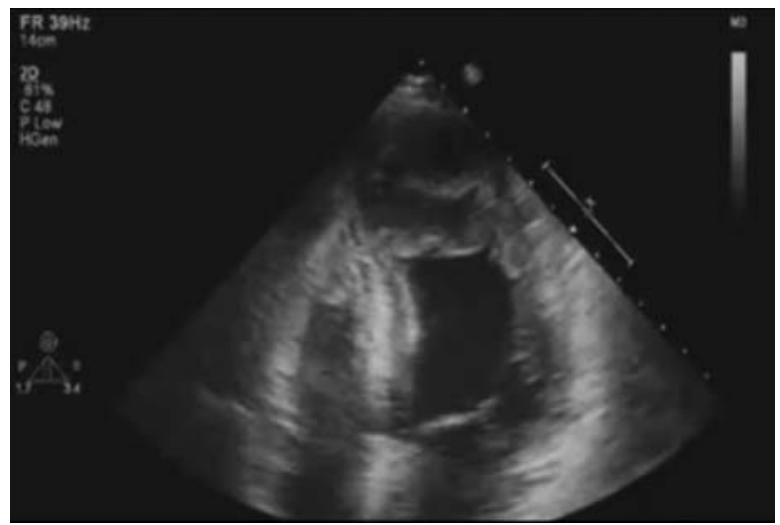

Video 1 Transthoracic four-chamber imaging taken on the admission day.

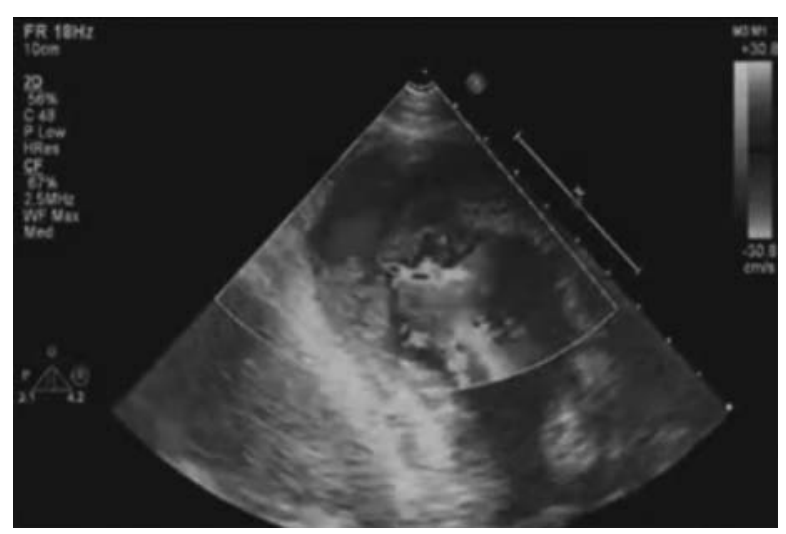

Video 2 Doppler colour flow imaging taken on the admission day.

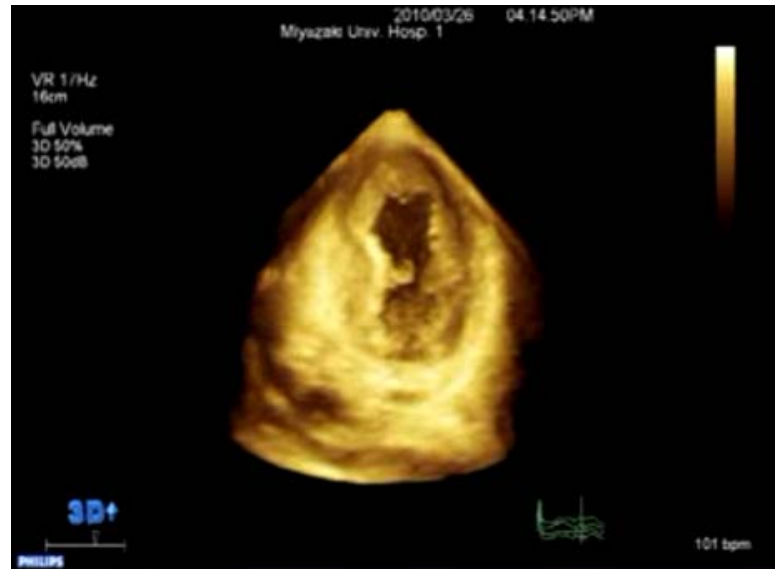

Video 3 3D echocardiogram taken on the admission day.

recording and $3 \mathrm{D}$ echocardiogram would improve the accuracy of diagnosis by recognising communication between the chamber of the ventricle and the dissected myocardium, flow within the dissecting myocardium and structural integrity of DIH. This case showed a benign prognosis under the conservative observation; however, some cases extending from the apex into the septum or right ventricle require surgical treatment. ${ }^{3}$

Competing interests None.

Patient consent Obtained.

\section{REFERENCES}

1. Dias V, Cabral S, Gomes C, et al. Intramyocardial dissecting haematoma: a rare complication of acute myocardial infarction. Eur $\mathrm{J}$ Echocardiogr 2009;10:585-7. 
2. Gisquet H, Liu H, Blondel WC, et al. Intradermal tacrolimus prevent scar hypertrophy in a rabbit ear model: a clinical, histological and spectroscopical analysis. Skin Res Technol 2011;17:160-6.
3. Vargas-Barrón J, Roldán FJ, Romero-Cárdenas A, et al. Dissecting intramyocardial hematoma: clinical presentation, pathophysiology, outcomes and delineation by echocardiography. Echocardiography 2009;26:254-61.

This pdf has been created automatically from the final edited text and images.

Copyright 2012 BMJ Publishing Group. All rights reserved. For permission to reuse any of this content visit http://group.bmj.com/group/rights-licensing/permissions.

BMJ Case Report Fellows may re-use this article for personal use and teaching without any further permission.

Please cite this article as follows (you will need to access the article online to obtain the date of publication).

Sakata K, Tsuruda T, Imamura T, Kitamura K. Postinfarction dissecting intramyocardial haematoma in a patient treated with immunosuppressant. BMJ Case Reports 2012;10.1136/bcr-2012-006904, Published XXX

Become a Fellow of BMJ Case Reports today and you can:

- Submit as many cases as you like

- Enjoy fast sympathetic peer review and rapid publication of accepted articles

- Access all the published articles

- Re-use any of the published material for personal use and teaching without further permission

For information on Institutional Fellowships contact consortiasales@bmjgroup.com

Visit casereports.bmj.com for more articles like this and to become a Fellow 